\title{
The erythrasma microorganism in situ: studies using the skin surface biopsy technique
}

\author{
R. MARKS, N. D. RAMNARAIN, B. BHOGAL, AND N. T. MOORE \\ From the Institute of Dermatology, St. John's Hospital for Diseases of the Skin, London, and the Depart- \\ ment of Crystallography, Birkbeck College, London
}

SYNOPSIS The skin surface biopsy technique has been used to investigate the erythrasma organism in situ in the stratum corneum in 11 patients. Staining by PAS and Gram stain showed the presence of a large number of organisms arranged haphazardly in some areas and in microcolonies in others. With the scanning electron microscope it was possible to see that smooth filamentous chains of microorganisms had penetrated horn cells and caused disturbance of the surface structure of these cells.

Enzyme histochemical tests showed that the erythrasma microorganism possessed a strong reactivity for NAD diaphorase and other mitochondrial enzymes. The reactivity was focal confirming a complex subcellular organization of organelles.

It is suggested that the erythrasma microorganism secretes a mucopolysaccharide sheath in some circumstances.

Erythrasma is a chronic scaly dermatosis affecting the body flexures and intertriginous areas of adults. Previously it was believed to be due either to a type of dermatophyte (Microsporum minutissimum) or an actinomycete (Nocardia minutissimum). In 1969, a diphtheroid termed Corynebacterium minutissimum was isolated from lesions of erythrasma and thought to be the causative agent (Sarkany, Taplin, and Blank, 1961). Still more recently Somerville (1970) suggested that several strains of fluorescent diphtheroid organisms were responsible for the clinical disorder that is recognized as erythrasma. In this study we describe the results of our investigations into the causative organism of erythrasma using the skin surface biopsy technique, which removes an intact layer of stratum corneum with a cyanoacrylate adhesive (Marks and Dawber, 1971). A general account of the use of this method for demonstrating pathogenic microorganisms in the stratum corneum is documented elsewhere (Marks and Dawber, 1972).

\section{Methods}

PATIENTS

The clinical details of the 11 patients with erythrasma who were investigated in this study are as follows: Received for publication 8 June 1972. all 11 patients were men, the average age was 48 and the age range 24 to 63 . In nine the groins were involved, in four the toe webs were involved, and in four the axillae were involved. It can be seen that the usual male predominance of the disease is evident in our group of patients. A coral pink fluorescence was detected in the involved sites when they were viewed in ultraviolet light and small fluorescing colonies of C. minutissimum were isolated on 199 plates from skin scales in all patients.

\section{SKIN SURFACE BIOPSIES}

These specimens were obtained using ethyl cyanoacrylate (Permabond, Staines, Middx). Drops of the adhesive were placed on glass microscope slides or coverslips. Samples taken onto coverslips were stored in the deep freeze at $-40^{\circ} \mathrm{C}$ before histochemical examination. Samples on microscope slides were examined by light microscopy after alcohol fixation (two minutes) and staining with periodic acid Schiff reagent (periodic acid 10 minutes, Schiff reagent 20 minutes) or Gram stain (methyl violet two minutes, Gram's iodine two minutes, with differentiation in equal parts of alcohol and acetone for four seconds and counterstaining in neutral red two minutes). These preparations were made permanent by mounting them with a coverslip and neutral mounting medium. 
ENZYME HISTOCHEMICAL INVESTIGATIONS

Skin surface biopsies from six patients were taken onto coverslips instead of microscope slides and were tested with the following enzyme histochemical reactions: (a) non-specific esterase (indoxyl acetate esterase method of Holt, 1954); (b) leucine aminopeptidase (sing L-leucyl 4 methoxy $-\beta$ naphthylamide as substrate and the method of Nachlas, Crawford, and Seligman, 1957); (c) NAD diaphorase, lactic dehydrogenase, succinic dehydrogenase, and beta-hydroxybutyric dehydrogenase (using NBT method of Pearse, 1960); and $(d)$ adenosine triphosphatase (using method of Wachstein, Meisel, and Niedzwiedz, 1960).

SCANNING ELECTRON MICROSCOPE STUDIES

Skin surface biopsies from three of the subjects were taken onto glass microscope slides. Areas from the specimen-bearing sites of these slides were cut to size, mounted on 'stubs', and then coated with carbon in an Edwards coating unit. The coated specimens were then viewed in a Cambridge stereoscan scanning electron microscope (SEM) at an accelerating voltage of $20 \mathrm{kv}$ at a $45^{\circ}$ tilt.

\section{Results}

Skin surface biopsies from the affected sites stained with PAS reagent or Gram stain demonstrated the presence of numerous fusiform microorganisms which were arranged in clusters, chains, or singly, and scattered over variously sized areas (Figs. 1a and 1b). The chains that were seen usually comprised three, four, or occasionally more, individual bacterial cells. The microorganisms appeared approximately three to four times as long as they were broad. With the PAS stain there was noticeable diffuse staining of the sites containing the microorganisms which was visible macroscopically. There did not appear to be a particular accentuation around hair follicles or sweat gland openings.

The results of the enzyme histochemical investigations are given in Table $I$. It can be seen that these bacteria possess a wide range of enzyme reactivities. Mitochondrial enzyme activities seemed particularly strong, especially NAD diaphorase and lactic dehydrogenase activities. The reaction products from the tests performed were not distributed diffusely within the individual bacterial cells, but appeared aggregated in well defined foci within each cell (Fig. 2).

With the SEM single rod-shaped and oval structures and chains were seen lying on, and embedded in, the surface of the individual cornified cells. Individual bacterial cells measured approximately $2 \mu \times 1 \mu$ although there was quite a wide range of

\begin{tabular}{|c|c|c|c|c|}
\hline $\begin{array}{l}\text { Enzyme } \\
\text { Activity } \\
\text { Tested }\end{array}$ & $\begin{array}{l}\text { No. } \\
\text { Positive }\end{array}$ & $\begin{array}{l}\text { No. } \\
\text { Negative }\end{array}$ & No Fungus & Total \\
\hline $\begin{array}{l}\text { Non-specific } \\
\text { esterase }\end{array}$ & 4 & 0 & 1 & 5 \\
\hline $\begin{array}{l}\text { Leucine } \\
\text { amino } \\
\text { peptidase }\end{array}$ & 1 & 1 & 0 & 2 \\
\hline $\begin{array}{l}\text { NAD } \\
\text { diaphorase }\end{array}$ & 5 & 0 & 0 & 5 \\
\hline $\begin{array}{l}\text { Lactic } \\
\text { dehydro- } \\
\text { genase }\end{array}$ & 4 & 0 & 1 & 5 \\
\hline ATPase & 1 & 0 & 0 & 1 \\
\hline $\begin{array}{l}\text { Succinic } \\
\text { dehydro- } \\
\text { genase }\end{array}$ & 2 & 0 & 0 & 2 \\
\hline $\begin{array}{l}\beta \text {-Hydroxy- } \\
\text { butyric } \\
\text { dehydro- } \\
\text { genase }\end{array}$ & 2 & 0 & 0 & 2 \\
\hline
\end{tabular}

Table I Summary of the results of the enzyme histochemical tests

sizes present (Fig. 3). The chains were formed by the apparent linking of several organisms. It is interesting to note that although individual bacteria were easilyz seen when they were isolated or single cells, it was@ only just possible to make out the shape of the individual microorganisms when they were arrang $8 \mathrm{~d}$ in a chain. The surface of the bacterial cells appeared regularly smooth without any obvious specializedo anatomical features at magnifications up to $2500 \overline{6}$. The number of organisms seen by SEM was smallo compared to the large number seen in similar pre-⿳⺈⿴囗十 parations viewed with the light microscope aftero staining. The chains of bacterial cells were frequently $\overrightarrow{0}$ seen to be penetrating the cornified cells. At the site of 3 penetration there were, in several scales, openings? that were two or three times larger than the diameter. of the microorganisms.

The involved cells of the stratum corneum had an irregular ridge pattern, mainly composed of low, broken, undulating ridges which sometimesi branched. The surrounding uninvolved cells often 3 possessed prominent villi resembling the surface structure of the scale in psoriasis and some other parakeratotic disorders (Dawber, Marks, and Swift $\frac{T}{0}$ 1972).

\section{Comment}

The skin surface biopsy method is well suited to the study of certain aspects of the microbiology of the skin. In particular, a good view is obtained of various? invading microorganisms in their 'natural habitat' so that the invasive process can be studied. In ${ }^{+}$ addition, the number of pathogens present can be $\frac{0}{0}$ directly estimated and it is also possible to observe $\overrightarrow{\mathbb{D}}$ 


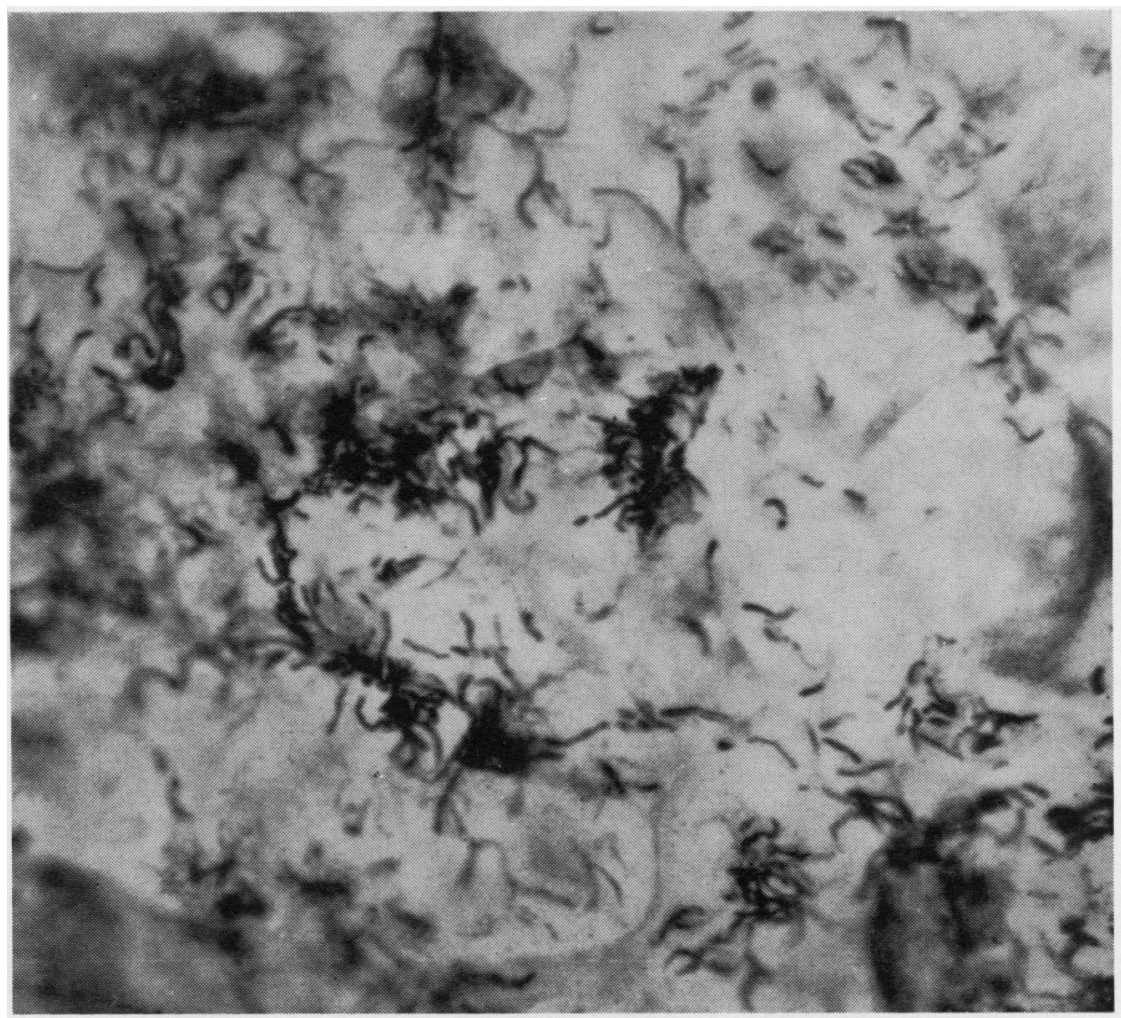

Fig. 1a Gram-stained preparation to show $C$. minutissimum ( $\times 250)$.

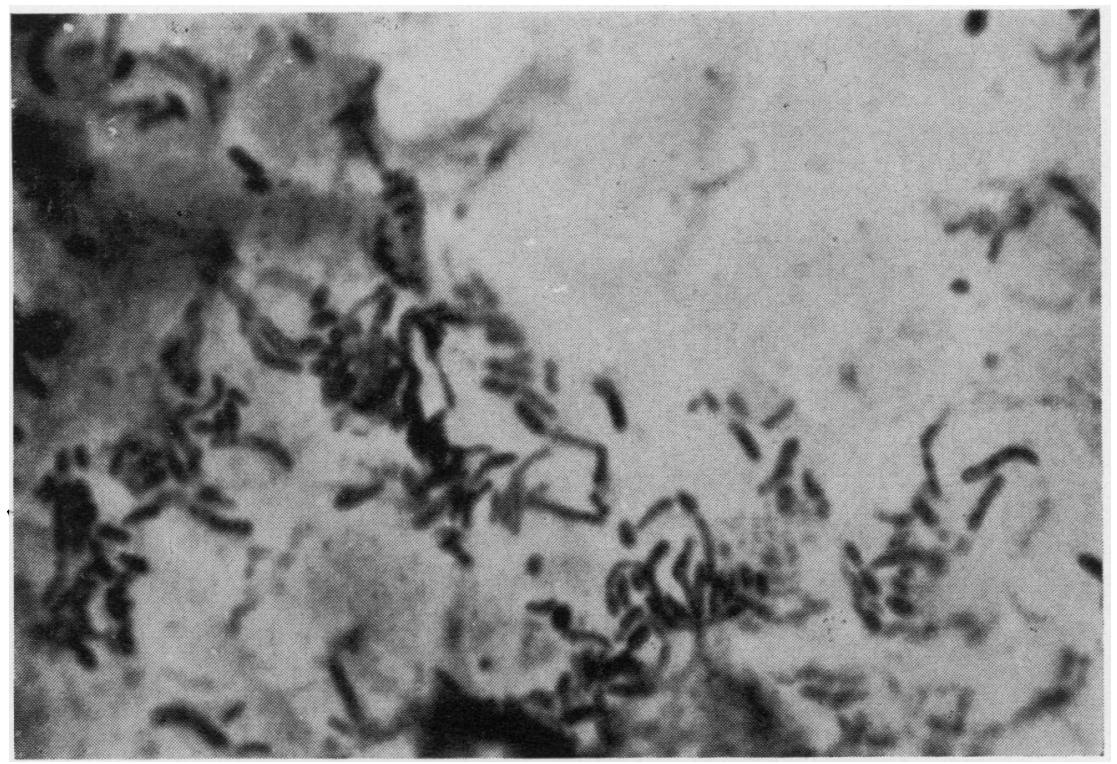

Fig. 1b Gram-stained preparation to show $C$. minutissimum ( $\times 480)$. 
R. Marks, N. D. Ramnarain, B. Bhogal, and N. T. Moore $\frac{c}{\bar{\Xi}}$

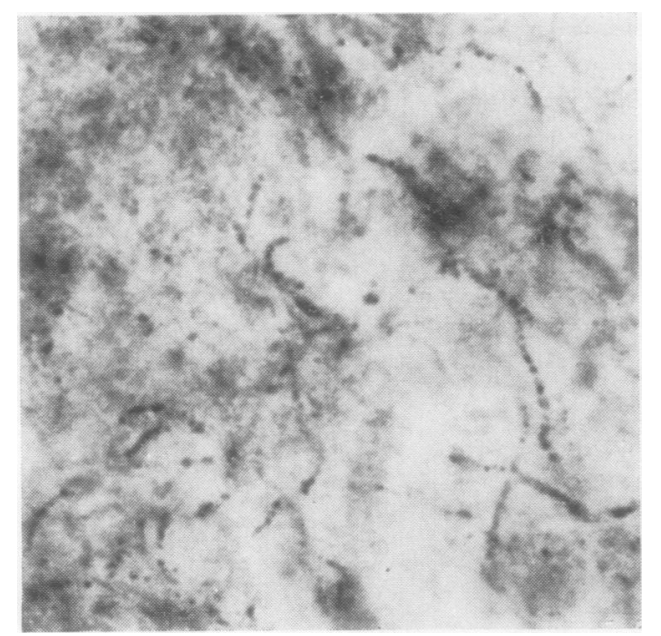

Fig. 2 Photomicrograph from skin surface biopsy tested with $N A D$ diaphorase reaction. Note focal aggregation of formazan reaction product $(\times 250)$. any morphological or histochemical changes caused by therapeutic measures.

In this study of erythrasma, several features have come to light that are worthy of comment. There $\vec{F}$ was a remarkable disparity between the numbers of $\stackrel{\mathcal{O}}{+}$ bacteria seen in stained preparations with the light $\frac{}{\circ}$ microscope and the numbers seen by SEM. This is $\frac{\overline{\bar{N}}}{\bar{D}}$ probably a reflection of the fact that the 'surface' scanned by SEM using the skin surface biopsy $\cong$ method is five or six cell layers down into the stratum corneum, while with the light microscope the $\overrightarrow{0}$ whole thickness of the specimen removed is exa- mined. Montes, Black, and McBride (1967) demon- $\vec{\omega}$ strated by conventional EM that the great majority? of the microorganisms of erythrasma did not invadeo further than the superficial part of the stratum N corneum. This must also be a major contributingio reason for the relatively small number of micro- 0 organisms seen by SEM in this study.

The surfaces of the horn cells into which the 의 microorganisms had penetrated possessed a dis- $\vec{c}$ organized ridge pattern, suggesting the possibility of $\left.\mathbb{D}^{(}\right)$

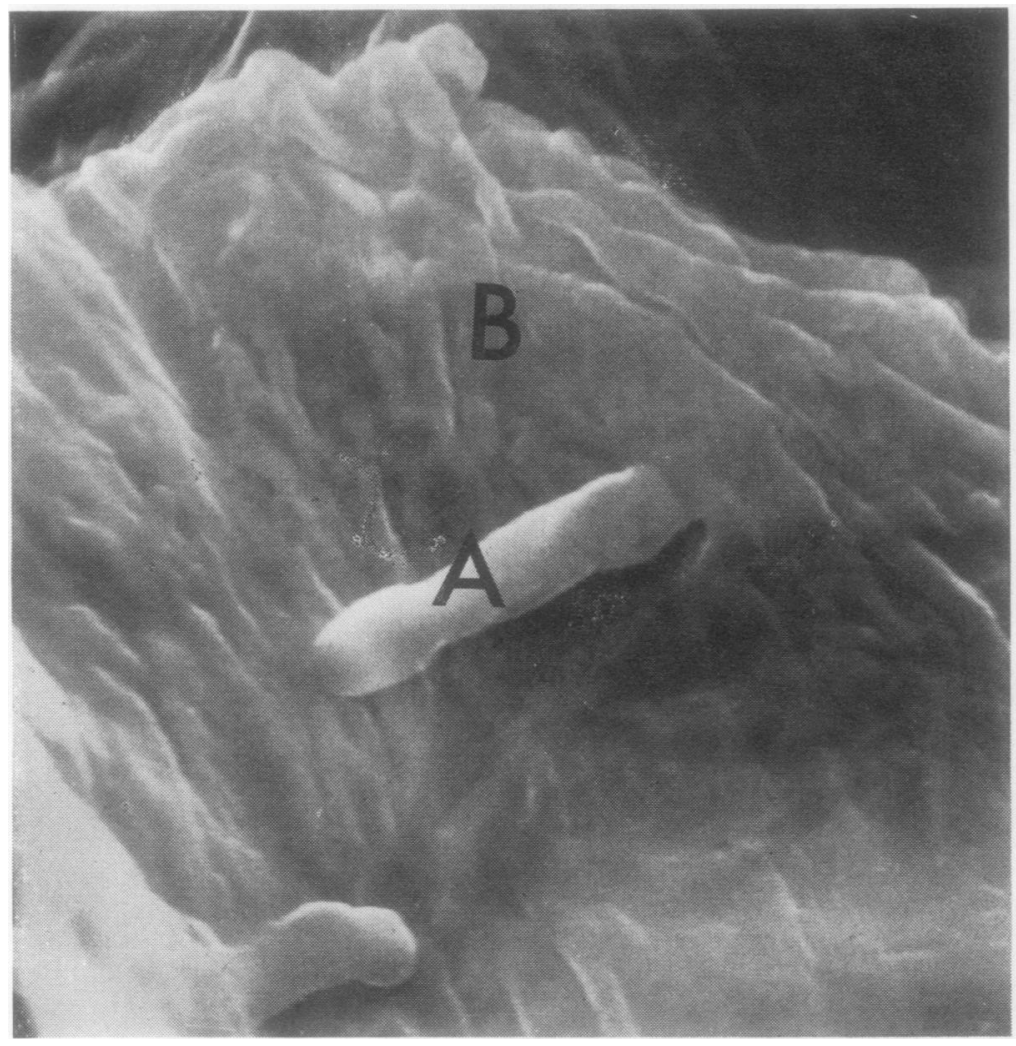

Fig. 3 Scanning electron micrograph from skin surface biopsy of erythrasma. Note filamentous chain of microorganisms $(A)$ emerging from a scale with a disorganized scale pattern $(B)(\times 4000)$. 
disruption of the system of tonofilament-desmosome complexes. In addition, the impression was gained that at the site of penetration the opening was, in some cases, much wider than the microorganisms. This might suggest that penetration was accomplished by a chemical dissolution rather than by purely physical pressure. Montes et al (1967) noted disorganization of 'keratin fibrils' in horn cells invaded by $C$. minutissimum and this would be in accord with our observations.

Strong enzyme reactivity of individual bacterial cells was detected and to our knowledge this metabolic activity has not been reported in this way before with the erythrasma organism. Some of the reaction products were obviously aggregated in well defined areas, confirming a complex subcellular arrangement akin to mammalian cells. A similar arrangement has been noted with enzyme reactions in the dermatophyte fungi (Meinhof, 1968).

We believe that the smooth exterior of the organisms observed by SEM, with only a slight constriction at the site of the junctions between microorganisms in a chain, plus the PAS reactivity of the microorganism (and its immediate environment) reflects the secretion of a mucopolysaccharide sheath by the organism in some situations. Somerville (1972) discussed the microbiology of the cutaneous diphtheroids and stated that the diphtheroids responsible for trichomycosis axillaris produced secretions that stick them together and to the hair, and cause, in addition, destruction of the hair keratin. A similar material may well be produced by $C$. minutissimum.

We are grateful to Dr Y. M. Clayton and the staff of the Mycology Department for help in this investigation, and to Drs W. C. Noble and D. A. Somerville for their helpful suggestions.

R.M. is in receipt of a grant from the MRC.

\section{References}

Dawber, R. P. R., Marks, R., and Swift, J. A. (1972). Scanning electron microscopy of the Stratum corneum. Brit. J. Derm., 86, $272-281$.

Holt, S. J. (1954). A new approach to the cytochemical localization of enzymes. Proc. roy. Soc. B., 142, 160-169.

Marks, R., and Dawber, R. P. R. (1971). Skin surface biopsy. Brit. J. Derm., 84, 117-123.

Marks, R., and Dawber, R. P. R. (1972). In situ microbiology of the stratum corneum. Arch. Derm., 105, 216-221.

Meinhof, W. (1968). Zum histochemischen Nachweis von Enzymen des energieliefernden Stoffwechsels in Dermatophyten der Gattungen Microsporum Epidermophyton und Keratinomyces. Arch. klin. exp. Derm., 232, 279-294.

Montes, L. F., Black, S. H., and McBride, M. E. (1967). Bacterial invasion of the Stratum corneum in erythrasma. J. invest. Derm., 49, 474-485.

Nachlas, M. M., Crawford, D. T., and Seligman, A. M. (1957). The histochemical demonstration of leucine aminopeptidase. $J$. Histochem. Cytochem., 5, 264-278.

Pearse, A. G. E. (1960). Histochemistry; Theoretical and Applied, 2nd ed. Churchill, London.

Sarkany, I., Taplin, D., and Blank, H. (1961). The etiology and treatment of erythrasma. J. invest. Derm., 37, 283-290.

Somerville, D. A. (1972). The microbiology of the cutaneous diphtheroids. Brit. J. Derm., 86, Suppl. 8, 16-20.

Somerville, D. A. (1970). Erythrasma in normal young adults. J. med. Microbiol., 3, 57-64.

Wachstein, M., Meisel, E., and Niedzwiedz, A. (1960). Histochemical demonstration of mitochondrial adenosine triphosphatase with the lead-adenosine triphosphate technique.J. Histochem. Cytochem., 8, 387-388. 